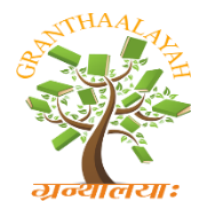

Science

\title{
DETERMINANTS OF HOUSEHOLD FOOD SECURITY AND COPING STRATEGY: (EVIDENCE FROM AMARO WOREDA OF SOUTHERN ETHIOPIA)
}

\author{
Alemnesh Diramo ${ }^{1}$, Rahmeto Negash ${ }^{1}$, Agidew Abebe ${ }^{1}$ \\ ${ }^{1}$ Department of Rural Development and Agricultural Extension, College of Agricultural \\ Science, Arba Minch University, Arba Minch, Ethiopia
}

\begin{abstract}
The study was conducted in Amaro Woreda of southern Ethiopia with the main objectives to identify the main determinants of household food Security. Data were analyzed by simple descriptive statistics (percentage, frequency and mean), inferential statistics (Chi-square and t-test) and logistic regression (binary logit) model. Household calorie acquisition was used to measure the status of household food security. Through systematic sampling method 151 respondents were identified. Among those $40.4 \%$ of the respondents were food insecure and $59.6 \%$ were food secure. The logistic model was initially fitted with 11 variables of which five were found to be significance effect on the household food security. Cultivated land size, livestock holding, education level, household labor and annual gross household income were significantly affecting household food security. Farm households have employed different coping strategies including sale of livestock, reduce size of meals and reduce number of meals at initial stage of food shortage and receive food aid, sale/consume seed meant and reduce size of meals at sever stage of food shortage. Improved food security is attained along with the increase in the size of cultivated land and livestock holdings. Improved technologies that increase the productivity of land and livestock should be given prior attention.
\end{abstract}

Keywords: Amaro; Woreda; Kebele; Food and Logit.

Cite This Article: Alemnesh Diramo, Rahmeto Negash, and Agidew Abebe. (2018). "DETERMINANTS OF HOUSEHOLD FOOD SECURITY AND COPING STRATEGY: (EVIDENCE FROM AMARO WOREDA OF SOUTHERN ETHIOPIA)." International Journal of Research - Granthaalayah, 6(5), 128-137. 10.29121/granthaalayah.v6.i5.2018.1434.

\section{Introduction}

Agricultural development is one of the most powerful tools end extreme poverty boost shared prosperity and Agriculture also crucial to economic growth. But agriculture-driven growth and poverty reduction, as well as food security are at risk (World Bank, 2017). 
Hunger remains an everyday challenge for almost795 million people undernourished worldwide, including 780 million in the developing regions, 15 million in developed countries. Sub-Saharan Africa accounts for 220 million undernourished and 23\% prevalence of undernourishment in 201416 (FAO, 2015). The global food security could be in jeopardy, due to mounting pressure on national resources and to climate change, both of which threaten the sustainability food system at large (FAO, 2017).

Africa remains the region with highest prevalence of under nourishment with around one in four people out of about one billion estimated to be undernourished. According to Federal Democratic Republic of Ethiopia (2010), concentrations of food insecurity and malnutrition are endemic in rural areas, with a population of six to seven million chronically food insecure, and up to 13 million seasonally food insecure.

According to Food Science Information Network (2017), food insecurity is expected to rise sharply in early 2017 in southern and Southeastern pastoral areas of Ethiopia. At present day 795 million people still suffer from hunger and more than two billion from micronutrient deficiencies. Therefore, this study intended to identify the determinants of food security.

\section{Statement of the Problem}

A number of factors aggravated the problem of food insecurity in Ethiopia. These are population pressure, drought, shortage of farmland, soil erosion, lack of oxen, deterioration of food production capacity, outbreak of plant and animal disease, poor soil fertility, frost attack, chronic shortage of cash income, poor farming technologies, weak extension services, high labor wastage and poor social and infrastructural facility and pre and post-harvest crop loss (Birara and Endalew, 2015).

About $10 \%$ of the country's population is food insecure with average consumption of approximately 1770 kilocalories per capita, which is considerably low as compared to FAO/WHO, recommended $2100 \mathrm{kcal}$ per AE per day. In spite of the improvement of main macroeconomic indicators in recent years, food security remains one of the most important issues in Ethiopia's development agenda. Indeed, food insecurity in some vulnerable regions is one of the major obstacles to poverty reduction. Both transitory and chronic food insecurity are common in Ethiopia. Moreover, food insecurity is one of the defining features of rural poverty affecting millions of people (FDRE, 2001).

The problem of food insecurity has wide diversity and multiple dimensions, which ranges from the global, regional, country, local, household to individual level. However, more attention is given to the country and regional levels. Food security and poverty reduction remains as a top issue as far as rural development is concerned. To ensure this objective governmental and non-governmental organizations are working in the area. However, significant research was not done on the understanding of determinants of household food security in the study area. Due to this, this study was intended on identify the determinants of household food security and coping strategy. 


\section{Objectives}

1) To assess household food security status in the study area.

2) To identify the determinants of food security in the study area.

3) To identify coping strategies of households in the study area.

\section{Materials and Methods}

An important decision that has taken while selecting a sampling technique is about the size of the sample. Appropriate sample size depends on various factors relating to the subject under investigation including time, cost and degree of accuracy. So that appropriate sample size has applied in order to get good representative data.

As it is practically impossible to reach all individuals or communities in the study area because of the limitations of human power, time and other resources it is wise to take representative samples to collect useful data.

In line with this, a multistage sampling procedure was used to select sample household. In the first stage, Amaro Woreda was selected purposely based on personal knowledge about the area and governmental and non-governmental organizations working towards poverty reduction in the area.

In the second stage, Kebeles in the Woreda were stratified based on their agro-ecology. In the third stage, from total of 33 rural Kebeles found in the Woreda 4 kebeles were randomly selected.

Based on proportionality in their agro-ecology, one Kebele from Highland, two kebeles from Midland and one from Low land were included in this study. Food security at household level is best measured by the direct survey of dietary intake. The data were obtained from seven day recall and daily consumption record was converted to kilocalorie using the food composition (EHNRI, 1997).

The consumed food was converted in to kilocalorie and then divided by household size. The amount of energy available for the household is compared with the minimum subsistence requirement per AE per day is $2100 \mathrm{kcal}$.

A total of 151 household were selected using probability proportional to sample size. The sample size was determined based on simplified formula provided by Yamane (1967) at 95\% confidence level 0.5 degree of variability and $8 \%$ level of precision.

Where $\mathrm{n}$ is the sample size,

$$
\begin{gathered}
n=\frac{N}{1+N(e) 2} \\
\mathrm{n}=\frac{4544}{1+4544(0.08) 2}=151 \text { household }
\end{gathered}
$$

$\mathrm{N}$ is the population size (total households in the four kebels which is 4544) and $\mathrm{e}$ is the level of precision.

Both qualitative and quantitative data were collected from primary and secondary sources. Quantitative primary data were collected using household survey, in which the household heads 
and their spouses were asked about food security and related issues. Qualitative primary data were collected using key informants where elderly and knowledgeable people about the area were asked on various issues relevant to the study, Kebele Development agents and Woreda Office food security expert. On the other hand, secondary data were obtained from published and unpublished sources.

After identifying the households as food secure and insecure groups, data were analyzed by simple descriptive statistics (percentage, frequency and mean), inferential statistics (Chi-square and t-test) and logistic regression (binary logit) model. Gujarati (1995), the functional form of logistic model is specified as follows:

$\Pi(\mathrm{x})=\mathrm{E}(\mathrm{Y}=\mathrm{f} / \mathrm{x})=1$

$\Pi(\mathrm{x})=\mathrm{E}(\mathrm{y}=1 / \mathrm{x})=1 / 1+\mathrm{e}-(\mathrm{Bo}+\mathrm{BiXi})$

For ease of exposition, we write (1) as:-

$\Pi(\mathrm{x})=1 / 1+\mathrm{e}-\mathrm{zi}$

Where $\Pi(\mathrm{x})=$ is a probability of being food secure ranges from 0 to 1

$\mathrm{Zi}=$ is a function of $\mathrm{n}$-explanatory variables $(\mathrm{x})$ which is also expressed as:

$\mathrm{Zi}=\mathrm{Bo}+\mathrm{B} 1 \mathrm{X} 1+\mathrm{B} 2 \mathrm{X} 2+$ $+\mathrm{BnX}_{\mathrm{n}}$

Where

X1=Age of household head

$\mathrm{X} 2=$ Sex of household head

$\mathrm{X} 3=$ Educational level of household head

$\mathrm{X} 4=$ Family size

$\mathrm{X} 5=$ Total annual household income

X6=Livestock ownership

$\mathrm{X} 7=$ Use of improved seed

$\mathrm{X} 8=$ Use of chemical fertilizer

X9Accesses to Credit

X10 DA contact

X11 Total cultivated land holding in ha

\section{Result and Discussion}

\section{Measuring the Food Security Status of the Households}

Measuring household food security using household caloric acquisition produces a crude estimate of the amount of calorie available for consumption in the household for specific period (Hoddinott, 2001)

Food security at household level measured in many ways. In this study, household caloric acquisition employed to measure household food security status. Household food or calorie acquisition/consumption per adult equivalent per day was used to identify the sample households as food secure and food insecure. Total calorie consumed by the household in seven days was compared with the minimum recommended calorie of $2100 \mathrm{kcal}$ per adult equivalent per day. Based on the result obtained from this calculation, the household categorized as food insecure if their caloric consumption is less than $2100 \mathrm{kcal}$ per adult equivalent per day and food secure if its consumption with in that period was $2100 \mathrm{kcal}$ per adult equivalent per day and above. 
As explained above the state of food security at household level was measured by direct survey of consumption on sample respondents. The data on the available food for consumption for the household (home produces, purchases or remittances/gifts or loans in kind) for the last seven (7) days were collected. The consumed portion of and the consumed food was converted to calorie then divided by household size. The amount of energy available for the household is compared with the minimum subsistence requirement per adult equivalent per day $2100 \mathrm{kcal}$.

Accordingly, the percent of food insecure (61) and secure households (90) were found that 40.4 percent and 59.6 percent, respectively. The mean value of food energy consumed by food insecure and secure households was $1808 \mathrm{Kcal} / \mathrm{AE} /$ day and $2481 \mathrm{Kcal} / \mathrm{AE} / \mathrm{day}$, respectively. The minimum and maximum value of food energy consumed by food insecure households was $1045 \mathrm{Kcal}$ and 2095 Kcal, respectively. Whereas the minimum and maximum values of food energy consumed by food secure households were $2106 \mathrm{Kcal}$ and $3645 \mathrm{Kcal}$, respectively.

Table1: Food Energy Consumed per adult equivalent per day among sample households

\begin{tabular}{|l|l|l|}
\hline $\begin{array}{l}\text { Calories consumed by } \\
\text { household }\end{array}$ & $\begin{array}{l}\text { Food insecure } \\
\text { household(61) }\end{array}$ & $\begin{array}{l}\text { Food } \\
\text { household(90) }\end{array}$ \\
\hline Minimum & 1045 & 2106 \\
\hline Maximum & 2095 & 3645 \\
\hline Mean & 1781.57 & 2499.74 \\
\hline
\end{tabular}

Source: computed from survey data, 2017.

\section{Descriptive and Inferential Results of Categorical Variables}

According to the survey results presented in Table2, The proportion of male headed households was 87 percent of total sampled food insecure households. In addition to this, male headed households accounted for 89 percent of the total food secure households. Whereas, the proportion of female headed households out of total sampled food secures households and food insecure female headed households were 11 percent and 13 percent respectively. The chi-square result shows that there was no statistically significance relationship between food security and sex of households head.

About $80 \%$ of food secure households, $70.4 \%$ of food insecure households were illiterates. The chi-square result shows that there was no statistically significance relationship between food security and education level of households head.

About $83.3 \%$ of food secure households, $78.7 \%$ of food insecure households have no access to credit. The chi-square result shows that there was no statistically significance relationship between food security and access to credit by households.

About $78.9 \%$ of food secure households, $64 \%$ of food insecure households have used improved seeds. The chi-square result shows that there was no statistically significance relationship between food security and use of improved seeds by households. 
About $76.7 \%$ of food secure households, $68.9 \%$ of food insecure households have used chemical fertilizer. The chi-square result shows that there was statistically significance relationship between food security and use of chemical fertilizer by households at $10 \%$ significance level.

Table 2: Descriptive and inferential results of categorical variables

\begin{tabular}{|c|c|c|c|c|c|}
\hline Variables & Categories & $\begin{array}{l}\text { Food insecure } \\
\text { household }(61)\end{array}$ & $\begin{array}{l}\text { Food secure } \\
\text { household }(90)\end{array}$ & $\chi^{2 \text {-value }}$ & $\begin{array}{l}\text { P- } \\
\text { value }\end{array}$ \\
\hline \multirow{2}{*}{$\begin{array}{ll}\text { Sex } & \text { of } \\
\text { respondent }\end{array}$} & Male & $53(87 \%)$ & $80(89 \%)$ & \multirow[t]{2}{*}{0.139} & \multirow[t]{2}{*}{0.449} \\
\hline & Female & $8(13 \%)$ & $10(11 \%)$ & & \\
\hline \multirow[t]{4}{*}{ Education level } & Illiterate & $18(11 \%)$ & $17(22 \%)$ & \multirow[t]{4}{*}{3.93} & \multirow[t]{4}{*}{0.282} \\
\hline & $\begin{array}{l}\text { Write and } \\
\text { read }\end{array}$ & $6(4 \%)$ & $10(7 \%)$ & & \\
\hline & Primary & $34(23 \%)$ & $52(34 \%)$ & & \\
\hline & Secondary & $3(2 \%)$ & $11(7 \%)$ & & \\
\hline \multirow[t]{2}{*}{ Access to credit } & Yes & $13(21.3)$ & $15(16.7)$ & \multirow[t]{2}{*}{0.525} & \multirow[t]{2}{*}{0.519} \\
\hline & $\mathrm{No}$ & $48(78.7)$ & $75(83.3)$ & & \\
\hline \multirow{2}{*}{$\begin{array}{l}\text { Used of } \\
\text { improved seed }\end{array}$} & Yes & $39(64)$ & $71(78.9$ & \multirow[t]{2}{*}{7.086} & \multirow[t]{2}{*}{0.291} \\
\hline & $\mathrm{No}$ & $22(36)$ & $19(21.1)$ & & \\
\hline \multirow{2}{*}{$\begin{array}{l}\text { Use of chemical } \\
\text { fertilizer }\end{array}$} & Yes & $42(68.9)$ & $69(76.7)$ & \multirow[t]{2}{*}{$2.314 *$} & \multirow[t]{2}{*}{0.075} \\
\hline & $\mathrm{No}$ & $19(31.1)$ & $21(23.3)$ & & \\
\hline
\end{tabular}

\section{Descriptive and Inferential Results of Continuous Variable}

As shown in the Table 3, the average age of food insecure and secure households were 41 and 43 respectively. The t-value shows that there is no statistical significance age difference between food insecure and secure household head.

The mean household size of food insecure and secure households was found 5.57 and 5.18 in adult equivalent. The t-value shows that, there is no statistical significant mean difference between the two groups.

The mean cultivated land of insecure and food secure households were $0.73 \mathrm{ha}$ and $1.13 \mathrm{ha}$, respectively. The $\mathrm{t}$-value shows that, there is significant mean difference between food insecure and food secure households at $10 \%$ significance level. This shows that land ownership has significant association with state of household food security.

Average livestock holding of the food insecure and food secure households was found to be 2.95 tropical livestock unit and 4.99 tropical livestock unit, respectively. The t-test value shows that there is significant difference between mean value of food insecure and food secure household at $1 \%$ significance level.

On average the sample food secure and insecure households earned 60109 and 11,757 annual gross income respectively.

The survey output also verified that food secure households have better income than food insecure households. The t-value verifies that there is significance mean difference between the two groups. 
Table 3: Descriptive and inferential results of continuous variable

\begin{tabular}{|l|l|l|l|l|}
\hline \multirow{2}{*}{ Variables } & \multicolumn{2}{|c|}{ Mean } & t-value & p-value \\
\cline { 2 - 5 } & $\begin{array}{c}\text { Food insecure } \\
\text { household (61) }\end{array}$ & \multicolumn{1}{c|}{$\begin{array}{c}\text { Food secure } \\
\text { household (90) }\end{array}$} & & \\
\hline Age of respondents'. & 42 & 43 & 0.863 & 0.39 \\
\hline $\begin{array}{l}\text { Household labor in } \\
\text { adult equivalent }\end{array}$ & 5.57 & 5.18 & -1.347 & 0.18 \\
\hline Cultivated Land Size & 0.73 & 1.13 & $2.273^{*}$ & 0.063 \\
\hline $\begin{array}{l}\text { Livestock holding in } \\
\text { tropical livestock unit. }\end{array}$ & 2.95 & 4.99 & $3.436^{* * * *}$ & 0.001 \\
\hline $\begin{array}{l}\text { Contact with } \\
\text { development agents }\end{array}$ & 2.44 & 2.54 & 0.333 & 0.739 \\
\hline $\begin{array}{l}\text { Annual gross } \\
\text { household income }\end{array}$ & 11,757 & 60,109 & $3.409^{* * * *}$ & 0.001 \\
\hline
\end{tabular}

\section{The Determinants of Food Security at Household Level}

Logistic regression model was used to identify determinants of food security at household level. Accordingly, variables assumed to have influence on household food security in different contexts were tested in the model (Table4) and out of 11 explanatory variables included in the model; five variables were found significant influence on the food security in the study area. These variables are: household size in $\mathrm{AE}$, educational level of household head, size of cultivated land, livestock ownership, and annual gross income.

Household Size in Adult Equivalent: Was significance at 1\% probability level and has positive association with household food security. The positive sign in the model output is an indication of probability of being food secure with an increase in family size. The odds ratio in favor of food security increase with increasing household size in AE by unit was found to be 0.494 . Households with large size in $\mathrm{AE}$, composed mainly of productive population could face the probability to be food secure due to high productive labor.

Disagreement with this finding Feleke and Zegeye (2006), have reported that labor availability and pressure on consumption is best described by household size. Adding more family creates more pressure on consumption than the labor it contributes. In this study, household size is a continuous variable which best explains the number of family members living in a household. Thus we expect that as the number of family in the household increases food security decreases whereas it has negative association household food security status.

Cultivated Land Size: is prominent resource expected to be associated with food security status. The model result pointed out that cultivated land size and household food security has positive relationship and significance at 10\% probability level. This means households with large cultivated land size produce more for household consumption and for sale and have better chance to be food secure than those having relatively small size of cultivated land.

The odds ratio for this variable was 0.680 . This implies that maintaining other determinants remain constant, additional hectare of cultivated land will enhance food security status of the household by factor of 0.680 and vice versa. 
Livestock Ownership in Tropical Livestock Unit: was found to have significance at less than $5 \%$ probability level and positive relationship with household food security. Most households accumulate their wealth in terms of livestock as they are prominent sources of wealth to farm households. Households with relatively large livestock size in TLU were found to be less vulnerable to food insecurity. In line with this, the odds ratio in favor of food security increase by factor of 1.243 for unit increment in TLU.

Annual Gross Household Income: This variable is found to have positive and significance influence at $5 \%$ probability level on the probability of being food secure. The result of this study supports the hypothesis that the larger income has positive effect on the probability of being food secure. The possible explanation is that, in the study area, households who managed to earn more cash income had very high chance of securing access to food than those who had not.

In other words, larger annual income may also affect the probability of being food secure by providing the source of cash flow to buffer the risk associated with crop failure due to bad weather condition. The interpretation of the odds ratio implies that, if other factors are held constant, the odds ratio in favor of the probability of being food secure increases by a factor of 1.000 as the farmers get unit of income.

Table 4: The result of the logit model

\begin{tabular}{|c|c|c|c|}
\hline Explanatory Variables & Coefficien & sWald S & Sig. Odds Ratio \\
\hline Age of $\mathrm{HH}$ & .026 & 1.731 & $.188 \mid 1.026$ \\
\hline Sex of HH & -.036 & .003 & .959 .965 \\
\hline Household size in adult equivalent. & $.494 * * *$ & 11.939 & .001 .610 \\
\hline Education level of respondent & $.436^{*}$ & 3.051 & \begin{tabular}{l|l}
.081 & 1.546 \\
\end{tabular} \\
\hline Annual household income & $.000 * *$ & 4.767 & .0291 .000 \\
\hline Livestock holding in tropical livestock unit. & $217 * *$ & 5.688 & .0171 .243 \\
\hline Use of improved seed & -.263 & .529 & 467.769 \\
\hline Use of chemical fertilizer & -.124 & .062 & 803.884 \\
\hline Access to credit & -.085 & .029 & 866.918 \\
\hline DA contact & -.148 & 1.788 & \begin{tabular}{|l|l|l}
.181 .862 \\
\end{tabular} \\
\hline Cultivated land in ha & $.680^{*}$ & 3.459 & $\begin{array}{l}.063 .507 \\
\end{array}$ \\
\hline Constant & .440 & .096 & $.757 / 1.552$ \\
\hline
\end{tabular}

$*$, **and $* * *$ Significance at $\mathrm{p}<, 10 \%, 5 \%$ and $1 \%$, respectively.

Source: computed from survey data of 2017.

\section{Local Coping Strategies}

Food shortage in the Woreda is common phenomenon in 7 lowland Kebeles and it occurs almost through years. Shortage of rain fall, problem of pest infestation, and shortage of farm land are some of the reasons for the occurrence of food shortage. The respondents employed different coping strategies to escape initial and severe stage of food shortage. The survey result shown that the food insecure households respond differently at different stages of food shortage. Sale of livestock (91\%), reducing portion and frequency of meals (83\% and $87 \%$ ), as their 1st, 2nd, 3rd, rank of coping strategies, respectively. 
Likewise the sample households respond differently when the food shortage becomes severe. Unlike the initial stage of food shortage, the households respond to the severe stage of food shortage in a different way. These are receive food aid $93 \%$ as their first option followed by sale /consume seed meant for next season planting86.8\%, they also employed reduce size of meals $81 \%$.

Table 5: Response categories of coping strategies at initial and severe stage of food insecurity

\begin{tabular}{|c|c|c|}
\hline \multicolumn{3}{|c|}{ Range of strategies in rank during initial stage by food insecure household } \\
\hline & $\mathrm{N}$ & $\%$ \\
\hline $1^{\text {st }}$ Sale of livestock & 56 & 91 \\
\hline $2^{\text {nd }}$ Reduce number of meals & 51 & 83 \\
\hline $3^{\text {rd }}$ Reduce size of meals & 53 & 87 \\
\hline \multicolumn{3}{|l|}{ Range of strategies in rank during sever stage } \\
\hline & $\mathrm{N}$ & $\%$ \\
\hline $1^{\text {st }}$ Food Aid & 57 & 93 \\
\hline $2^{\text {nd }}$ Sale/consume seed meant for consumption & 53 & 86.8 \\
\hline $3^{\text {rd }}$ Reduce size of meals & 50 & 81 \\
\hline
\end{tabular}

Source: Owen survey, 2017

\section{Conclusion and Recommendation}

According to the result of the study $61(40.4 \%)$ and $90(59.6 \%)$ of sample households were found to be food insecure and food secure respectively. Food secure households were characterized by relatively large resource endowments (land and livestock holdings, and significant income from crop production, livestock sale and non-farm activities, well educated, better use of intense practice in soil and water conservation measures.

T-test among potential continuous variables was employed to look into their influence on state of household food security. Factors including, cultivated landholding, livestock ownership, and annual income significantly influence household food security. On the other hand variables /such as education and family size were found to have significant association with household food security status.

In the logistic regression model, household size has significance and positive relationship with state of household food security. The rest of the variables, such as education, total annual income, livestock ownership, and cultivated land in ha have as expected, display positive and significant association with household food security. Farm households with large land size, number of livestock and high income were found to be less prone to food insecurity. Active involvement in non-farm activities does significantly affect food security in the study area. Therefore, improved food security is attained along with the increase in the size of cultivated land and livestock holdings. On the other hand, improved technologies that increase the productivity of land and livestock should be given prior attention.

Coping strategies employed at different stages include, sale of livestock reducing number food aid, sale/consume seed meant for consumption and reduce size of meals. Nearly $91 \%, 83 \%$ and $87 \%$ of the vulnerable groups use sale of livestock, reducing size of meals, skipping meals as their 1 st, 
2nd and 3rd coping strategy during the initial stage of food shortage. Similarly, 93\%, 86.8\% and $81 \%$ of the vulnerable households receive food aid, employ sale/ consume seed meant for consumption and reduce size as their $1_{\mathrm{st}}, 2^{\text {nd }}$ and $3 \mathrm{rd}$, coping strategy during the sever stage of food stress.

\section{Acknowledgement}

The researchers' have greatly acknowledged the Arba Minch University for its financial support.

\section{Conflict of Interest}

The authors have no conflict of interest.

\section{References}

[1] Birara. Endalew, M. M. (2015). Assesement of food securty situtation in Ethiopia. Asian Jornal of Agricultural Resarch, 1819-1894.

[2] Ethiopia Health and Nutrition Research Institute (EHNRI). (1997). Annual report of 1997.

[3] Federal Democratic Republic of Ethiopia (FDRE). (2001). Food Securty Startagy.

[4] Federal Democratic Republic of Ethiopia (FDRE).(2010). Food security strategy

[5] Feleke and Zegeye, (2006). Adoption of improved maize varieties in southern Ethiopia: Factors and strategies

[6] Food and Agricultural Organization (FAO). (2015). The state of food insecurtyin the world. meetine the 2015 internatinal hungre.

[7] Food and Agricultural Organization (FAO). (2017). The future of food Agriculture - Trends and challenges . Rome .

[8] Food Science Information Network (FSIN). (2017). Global Report on Food Crises.

[9] Gujarati (1995). Basic Econometrics

[10] World Bank (WB) (2017). The over view of Agriculture. April 04, 2017.

[11] Yemane (1967). Sampling Techniques: Sample size determination.

*Corresponding author.

E-mail address: agidew.abebe@gmail.com 